The Journal of Animal \& Plant Sciences, 30(3): 2020, Page: 642-648

ISSN (print): 1018-7081; ISSN (online): 2309-8694

\title{
EFFECT OF TANACETUM PARTHENIUM ON SERUM AMYLOID A AND SIALIC ACID IN DOGS WITH PSEUDOMONAS AERUGINOSA SKIN INFECTION
}

\author{
M. Andonova \\ Department of General and Clinical Pathology, Faculty of Veterinary Medicine, Trakia University, Bulgaria \\ *Corresponding author's E-mail: andonova_m@yahoo.com
}

\begin{abstract}
The effect of Tanacetum parthenium (feverfew) on serum amyloid A (SAA) and free sialic acid (SA) were investigated in dogs. The animals were divided into three groups: healthy dogs (Group I; $n=5$ ), dogs infected subcutaneously with $1 \times 10^{8} \mathrm{CFU} / \mathrm{mL}$ field $P$. aeruginosa culture (Group II; $\mathrm{n}=5$ ) and infected dogs treated with feverfew (90 mg standardised extract, $0.7 \%$ parthenolide) (Group III; $n=5$ ). Oral phytopreparation ( 2 capsules daily) intake began from post infection hour 4 and lasted 6 days. SAA concentrations increased insignificantly in infected dogs $(16 \mathrm{mg} / \mathrm{L})$ while infected dogs treated with feverfew exhibited more than 100-fold increase between post infection hours 24-72 vs Group II. Substantial differences $(\mathrm{p}<0.01)$ were identified vs Groups I and II at post infection hour 4, 48 and 72, but one day after feverfew discontinuation (day 7), they were not found out. Serum SA was low in controls (1.65-2.3 mmol/L) increasing by hour 72 in Groups II and III $(\mathrm{p}<0.01)$ to 2.8 and $3.49 \mathrm{mmol} / \mathrm{L}$ respectively. Positive correlation between both studied markers was present only in infected dogs receiving feverfew (Spearman's coefficient of rank correlation=0.410, $\mathrm{P}=0.0086$, $\mathrm{n}=40$ ). Tanacetum parthenium is reported to have medicinal activity in our canine skin infection model.
\end{abstract}

Key words: dogs, $P$. aeruginosa, infection, feverfew, serum amyloid A, sialic acid https://doi.org/10.36899/JAPS.2020.3.0076

Published online March 25, 2020

\section{INTRODUCTION}

Despite the variety of synthetic chemotherapeutics and antibiotics, the control of pseudomonad infections is still a challenge (Donadio et al., 2010). The attempts for direct attack on Gram-negative bacterium $P$. aeruginosa with nanofibre incorporated antimicrobial substances did not show promising results (Heunis and Dicks, 2010). On that background, medicinal plants with antimicrobial effect could be alternative and efficient treatment tools (Nascimento et al., 2000; Pourianezhad et al., 2016). Tanacetum parthenium (feverfew) is an aromatic plant with antibacterial (Izadi et al., 2010; Polatoğlu et al., 2010; Izadi et al., 2013) antiviral (Pareek et al., 2011) antifungal (Farzaneh et al., 2002) insecticidal (Polatoğlu et al., 2011) antiprotozoal effects (Izumi et al., 2008). Its wide spectrum of biological activities includes analgesic, antipyretic and antiinflammatory properties (Pareek et al., 2011; George et al., 2012; Mathema et al., 2012). Andonova et al. (2015, $2016,2017)$ analyzed the effects of the medicinal herb feverfew on innate defense mechanisms in dogs with experimental $P$. aeruginosa infections, while Smolinski and Pestka $(2003,2005)$ used murine models. In order to elucidate pathogenetic mechanisms of $P$. aeruginosa, Alhazmi (2015) proposed an in vitro model although data did not correspond to clinical cases where numerous extrinsic and intrinsic factors influence the course of infection. Martin et al. (2008), Saewan and Jimtaisong
(2013) provided proofs for the photoprotective benefits of feverfew in human clinical studies.

In vivo effects of Tanacetum parthenium on acute phase response, an integral part of innate immunity in human and animal infections of the skin are scarce.

The production, kinetics and indication possibilities of its products - acute phase proteins (APPs) (Eckersall and Bell, 2010; Langhorn et al., 2013) depend on inflammatory stimuli and the biological species (Murata et al., 2004). The variety of APPs, as well as the different magnitude of occurring changes in their levels necessitates their accurate selection.

Serum amyloid A (SAA) is a major acute phase protein (APP) in many species (cattle, horses, dogs, cats) (Hulten et al., 1997; Ceron et al., 2005), but data on its use as a marker of inflammation are inconsistent. According to Christensen et al. (2014), Schmidt and Eckersall (2015) SAA has a good general diagnostic value in inflammation, infections while Jitpean et al. (2014) affirmed that it changed only after a severe systemic inflammation. Additional studies on the diagnostic potential of this positive APP are necessary (Christensen et al., 2012, 2013, 2014) to elucidate its various immunomodulatory effects (Sack, 2018). The sialic acid (free, lipid-bound and protein-bound) which plays important role in a number of biological processes, cellular interactions, signalling pathways has also raised a number of questions (Mohebbi et al., 2010). Hartnell et al. (2001), Citil et al. (2004) affirmed that the Nacetylneuraminic acid is a marker of inflammation while others (Mohebbi et al., 2010; Khoshvaghti and Nazifi, 
2012; Nazifi et al., 2012) discussed it as an APP. This has raised our interest to changes in both APPs in dogs with skin infection, treated or not with feverfew, due to the lack of literature data.

The aim of this study was to investigate the in vivo effect of Tanacetum parthenium (feverfew) on the APPs serum amyloid A and free sialic acid as well as their correlation in healthy dogs, dogs with experimental $P$. aeruginosa skin infection and infected dogs treated with feverfew.

\section{MATERIALS AND METHODS}

Animals: Experiments were approved by the Ethical Committee of National Veterinary Service in Bulgaria (permit No. 37) and performed in accordance with the animal welfare standards. Fifteen clinically healthy male mixed-breed dogs aged 2-5 years were obtained from a licensed kennel. The animals were vaccinated against canine infectious hepatitis, distemper, leptospirosis, and rabies. The treatment against ectoparasites included antiparasitic shampoo Friskies (Viale G.Richard, Milano, Italia) and permethrin and carbaryl (Tapilan-B - Dorvert, Israel), and anthelminthic treatment comprised praziquantel and abamectin (Prazimec D - Biovet Ltd, Peshtera, Bulgaria) at a dose of 1 tablet $/ 10 \mathrm{~kg}$ body weight. The dogs were kept under similar housing and management conditions for acclimatization for a month and fed with a commercial diet according to the manufacture's prescriptions with free access to water.

Experimental design: The dogs were divided into 3 groups: Group I $(n=5)$ were untreated (controls). Dogs from Group II $(n=5)$ were subcutaneously infected with $P$. aeruginosa bacterial culture. A bacterial field strain culture in stationary phase with density corresponding to $1 \times 10^{8} \mathrm{CFU} / \mathrm{mL}$ was prepared nephelometrically according to the MacFarland standard (Quinn et al., 1999). Dogs from Group III $(\mathrm{n}=5)$ were infected with $P$. aeruginosa as those from Group II and received orally the phytopreparation feverfew (standardised extract, 90 mg, $0.7 \%$ parthenolide - Nature's Way, USA) beginning from the $4^{\text {th }}$ post infection hour for 6 consecutive days at a daily dose of 2 capsules.

Blood samples and serum analysis: Blood for analysis was collected in all groups from $\mathrm{v}$. cephalica antebrachii before the infection $(0 \mathrm{~h})$, and on post infection hours 4 , 24, 48, 72 and days 7, 10 and 14. Sera were separated after 30-minute stay at room temperature, followed by 15-minute storage in a refrigerator and centrifugation for 10 minutes at $3000 \times \mathrm{g}$ and stored in plastic vials at -20 to $-80^{\circ} \mathrm{C}$. Serum concentrations of canine SAA $(\mathrm{mg} / \mathrm{L})$ were determined by ELISA kit (Cat no. TP-802) (Tridelta PhaseTM Range SAA Assay, Tridelta Development Ltd,
Kildare, Ireland) specially developed for dogs according to the manufacturer's instructions. Serum free sialic acid concentrations $(\mathrm{mmol} / \mathrm{L})$ were assayed by the spectrophotometric method of Sydow (1985), a modification of the method reported by Shamberger (1984).

Statistical analysis: Normal distribution of data was evaluated by the Kolmogorov-Smirnov test. As data were not normally distributed, results were presented as median and range (min-max). Differences within each group were tested by the Kruskal-Wallis test (Dunn post hoc test) while between-group differences - by the MannWhitney non-parametric test. The relationships among the different variables were examined by Spearman rank correlation analysis. All statistical tests were performed with MedCalc 10.2.0.0, Belgium) software.

\section{RESULTS}

Data about SAA concentrations (Table 1) showed that in healthy dogs, this major APP ranges from $0 \mathrm{mg} / \mathrm{L}$ to a maximum of $7.4-7.6 \mathrm{mg} / \mathrm{L}$. The subcutaneous injection of $P$. aeruginosa broth culture in dogs from Group II did not alter statistically significantly its levels but by post infection hours 24 and 48, the APP increased to peak levels of $15.8 \mathrm{mg} / \mathrm{L}$ and $16.0 \mathrm{mg} / \mathrm{L}$. On the contrary, in dogs from Group III (infected and orally treated with the phytopreparation feverfew), SAA exhibited more than 100-fold increase: $156.6 \mathrm{mg} / \mathrm{L}$ on hour $24 ; 204.9 \mathrm{mg} / \mathrm{L}$ on hour $48(\mathrm{p}<0.05 \mathrm{vs} 0 \mathrm{~h})$, and $479.4 \mathrm{mg} / \mathrm{L}$ on hour $72(\mathrm{p}<0.01$ vs $0 \mathrm{~h})$. SAA levels differed significantly $(\mathrm{p}<0.01)$ vs Groups I and II by the post treatment hours 4,48 and 72 , but one day after oral administration of feverfew was discontinued, no relevant between-group different were found out.

Free sialic acid (Table 2) in healthy control ranged between $1.26 \mathrm{mmol} / \mathrm{L}$ and $2.42 \mathrm{mmol} / \mathrm{L}$. In infected untreated dogs (Group II), its concentration increased only by the $72^{\text {nd }}$ hour to a maximum of 3.38 $\mathrm{mmol} / \mathrm{L}$, but no statistically significant intra- and between group differences were proved. Infected dogs treated orally with feverfew reacted with substantially increased sialic acid concentration by post infection hour 48 $(\mathrm{p}<0.05$ vs Group I and II) and hour $72(\mathrm{p}<0.01$ vs Group I and II) when the peak value of $4.4 \mathrm{mmol} / \mathrm{L}$ was attained.

Spearman rank correlation analysis showed no statistically significant relationship between SAA and SA in controls ( $\mathrm{rho}=0.0883, \mathrm{P}=0.5881, \mathrm{n}=40$ ) and in infected only dogs (rho-0.00729, $\mathrm{P}=0.9644, \mathrm{n}=40$ ), while in the feverfew-treated infected group, a strong positive correlation between both parameters was found $(\mathrm{rho}=0.410$, $\mathrm{P}=0.0086, \mathrm{n}=40)$. 
Table 1. Dynamics of serum amyloid A concentrations (mg/L) in control dogs (Group I), dogs with experimental skin $P$. aeruginosa infection (Group II) and dogs with experimental skin $P$. aeruginosa infection treated with feverfew (Group III). All data are presented as median [min-max range]; $n=5$.

\begin{tabular}{|c|c|c|c|c|}
\hline Post infection period & $\begin{array}{l}\text { Controls } \\
\text { Group I }\end{array}$ & $\begin{array}{c}\text { Skin infection } \\
\text { Group II }\end{array}$ & $\begin{array}{c}\text { Infection+feverfew } \\
\text { Group III }\end{array}$ & P between groups \\
\hline $0 \mathrm{~h}$ & $0[0-0]$ & $0.1[0-0.7]$ & $1.3[0.2-3.0]$ & \\
\hline $4 \mathrm{~h}$ & $0[0-1.3]$ & $0.2[0-0.4]$ & $1.1[0.3-5.3]$ & $\begin{array}{l}\mathrm{P}_{\mathrm{I}-\mathrm{IIII}}<0.01 \\
\mathrm{P}_{\text {II-III }}<0.01\end{array}$ \\
\hline $24 \mathrm{~h}$ & $0[0-7.4]$ & $4.2[3.6-15.8]$ & $156.6[34.3-300.9]$ & $\mathrm{P}_{\mathrm{I}-\mathrm{III}}<0.01$ \\
\hline $48 \mathrm{~h}$ & $0[0-0.6]$ & $7.7[0-16.0]$ & $204.9 *[98.7-680.0]$ & $\begin{array}{l}\mathrm{P}_{\mathrm{I}-\mathrm{III}}<0.01 \\
\mathrm{P}_{\mathrm{I}-\mathrm{III}}<0.01 \\
\mathrm{P}_{\mathrm{II}-\mathrm{III}}<0.01\end{array}$ \\
\hline $72 \mathrm{~h}$ & $0[0-0.7]$ & $0.5[0-0]$ & $\begin{array}{c}479.4 * *[233.0- \\
661.6]\end{array}$ & $\begin{array}{l}\mathrm{P}_{\text {I-IIII }}<0.01 \\
\mathrm{P}_{\text {II-III }}<0.05\end{array}$ \\
\hline $7 d$ & $0[0-2.5]$ & $0[0-0]$ & $2.2[0.8-14.7]$ & \\
\hline $10 \mathrm{~d}$ & $0[0-0]$ & $0[0-0.2]$ & $3.0[1.3-3.9]$ & $\mathrm{P}_{\text {IIIIII }}<0.01$ \\
\hline $14 d$ & $0[0-7.6]$ & $0[0-0]$ & $2.7[1.1-3.6]$ & $\mathrm{P}_{\text {IIIIII }}<0.05$ \\
\hline
\end{tabular}

$* \mathrm{P}<0.05 ; * * \mathrm{P}<0.01$ vs $0 \mathrm{~h}$

Table 2. Dynamics of serum free sialic acid concentrations (mmol/L) in control dogs (Group I), dogs with experimental skin $P$. aeruginosa infection (Group II) and dogs with experimental skin $P$. aeruginosa infection treated with feverfew (Group III). All data are presented as median [min-max range]; $n=5$.

\begin{tabular}{ccccc}
\hline Post infection period & $\begin{array}{c}\text { Controls } \\
\text { Group I }\end{array}$ & $\begin{array}{c}\text { Skin infection } \\
\text { Group II }\end{array}$ & $\begin{array}{c}\text { Infection+feverfew } \\
\text { Group III }\end{array}$ & P between groups \\
\hline $0 \mathrm{~h}$ & $1.9[1.44-2.42]$ & $1.76[1.53-2.0]$ & $1.52[1.26-2.00]$ & \\
$4 \mathrm{~h}$ & $2.3[1.44-2.55]$ & $1.48[1.03-1.77]$ & $2.24[1.18-3.76]$ & \\
$24 \mathrm{~h}$ & $2.0[1.38-2.31]$ & $1.41[1.23-1.57]$ & $1.55[1.38-2.18]$ & \\
$48 \mathrm{~h}$ & $1.7[1.4-1.92]$ & $1.31[1.15-1.53]$ & $1.20[0.71-2.08]$ & $\mathrm{P}_{\mathrm{I}-\mathrm{IIII}}<0.05$ \\
& & & & $\mathrm{P}_{\mathrm{II}-\mathrm{III}}<0.05$ \\
$72 \mathrm{~h}$ & $1.79[1.45-2.0]$ & $2.80[2.68-3.38]$ & $3.49[2.33-4.40]$ & $\mathrm{P}_{\mathrm{I}-\mathrm{III}}<0.01$ \\
& & & & \\
$7 \mathrm{~d}$ & $1.86[1.26-2.42]$ & $1.64[1.45-2.83]$ & $1.71[1.43-2.02]$ & \\
$10 \mathrm{~d}$ & $1.65[1.5-2.0]$ & $1.74[1.23-1.94]$ & $1.69[0.82-2.79]$ & \\
$14 \mathrm{~d}$ & $1.75[1.29-2.2]$ & $1.76[1.59-2.39]$ & $1.74[1.45-3.59]$ & \\
\hline
\end{tabular}

\section{DISCUSSION}

The information for infectious agent, its virulence and site of host penetration is essential for adequate decision-making in infection control. The course of infection, however, largely depends on systemic defense potential and compensatory mechanisms. In our in vivo model of skin $P$. aeruginosa infection, many of environmental conditions influencing the infection are controlled. The analysis of results is however difficult, as the microbial pathogen attacks the host using a rich arsenal of virulence factors (He et al., 2004; Fu et al., 2010; Cabot et al., 2012; Alhazmi et al., 2015). The multicomponent defense system whose task is to combat and eradicate the pathogen, its products and disorders it may have caused mobilises numerous intricately interrelated cellular and humoral elements, which are controlled by local, neuroreflectory, humoral and hormonal mechanisms (Lavoie et al., 2011). That is why, parameters indicating occurring homeostasis disturbances that would permit to differentiate the extent of damage and to evaluate systemic defense potential, is essential. The fact that in healthy individuals APPs values are low but in homeostatic disorders their concentrations rapidly changes, allowed researchers recommending their use in clinical practice (Cray et al., 2009; Jain et al., 2011; Kjelgaard-Hansen and Jacobsen, 2011). In our experiment, the major canine APP serum amyloid A had low values in healthy controls throughout the study: from 0 to $1.3 \mathrm{mg} / \mathrm{L}(\min 0$; $\max 7.6 \mathrm{mg} / \mathrm{L})$. Under physiological conditions, Kim et al. (2013) also established very low APPs levels. Hadẑimusić and Hrković (2018) using a commercial ELISA, reported normal SAA concentration of $4.87 \pm 0.73 \mathrm{mg} / \mathrm{L}$ in dogs. In most available reports, SAA has been assayed via automated latex bead based immunoturbidometric assay (LZ-SAA, Eiken Chemical Co.) (Yamamoto et al., 1993; Christensen et al., 2012). 
The existing methodological difficulties, presence of multiple isoforms of SAA (Sellar et al., 1991), and numerous dog breeds impede the specification of SAA reference ranges and limit the use of this APP in routine veterinary clinical biochemistry (Petersen et al., 2004; Kjelgaard-Hansen and Jacobsen, 2011).

In dogs from Group II, SAA concentrations increased insignificantly to a peak value of $16 \mathrm{mg} / \mathrm{L}$ by post infection hour 48. This findings did not correspond to numerous reports outlining this APP as a marker of inflammation and infection (Eckersall and Bell, 2010; Langhorn et al., 2013), but agreed with other studies, e.g. in dogs with dental problems (Buttke et al., 2005) and dogs with cystitis, anal sacculitis, chronic dermatitis (Christensen et al., 2013). Considering that skin immune protection is potent, it could be hypothesised that the local cascade of mediators, cytokines and enzymes released from activated skin cells, although responsible for inflammation signs (swelling, pain, redness, heat) did not provide a sufficiently strong inflammatory impulse for intensive APPs production. That is why, although SAA is a major positive APPs in dogs, its alterations in $P$. aeruginosa infection of the skin and soft tissues are not relevant in this species.

In infected dogs treated with feverfew (Group III) however, serum amyloid A increased drastically between post infection hours 24 and 72, with more than 100 -fold higher values than those in Group II. It is therefore clear that differences between the two groups were rather a result from the application of the phytopreparation that has started from the post infection hour 4 to post infection day 6 . It could be presumed that SAA elevation in Group III could be due to its intensive liver synthesis or extrahepatic production (Upragarin et al., 2005), but this would imply the presence of a potent inflammatory stimulus raised by proinflammatory cytokines and chemokines. Feverfew is a phytopreparation with anti-inflammatory effect due to blockade of nuclear factor kappa-beta (NF-kB) reported earlier in this model (Andonova et al., 2015). Uluçкаn et al. (2015) outlined the role of activator protein-1 (AP-1), suggesting that SAA expression could result from transcriptional activation of AP-1. The six day phytopreparation intake by infected dogs exerted a direct effect on the intestinal mucosa. Meek and Benditt (1986) demonstrated amyloid A gene family expression in epithelial cells of the small and large intestine. Chu et al. (2018) showed a group of 3 innate lymphoid cells in gut associated lymphoid tissues, taking part in innate mucosal immune defense that being activated, release a substantial amount of proinflammatory cytokines. Yet, the molecular mechanisms underlying the distribution, regulation, functions of this defense cell population of gastrointestinal lymphoid tissue and its interactions with other cells elements and intestinal microbiota are unclear (Sawa et al., 2011). In their studies, Chen and Cheng (2009) identified 400 genes that are consistently regulated by feverfew extracts and hypothesised that feverfew components mediated metabolism, cell migration and cytokine production in human monocyte/ macrophages. Smolinski and Pestka (2005) found out 1.4 times enhanced IL-6 expression in the spleen than in the liver of mice although they were treated with the combination LPS+parthenolide (the primary active component of Tanacetum parthenium). The belief that the strong inflammatory stimulus for extrahepatic SAA synthesis was due to cytokine release following cellular elements destruction by feverfewinduced attacks of their membrane lipids seems inconsistent because SAA concentrations did not persist high during the 6 day phytopreparation intake but increased considerably only to post infection hour 72 time of acute phase response. As the latter is a dynamic homeostatic event aimed at neutralisation of the challenging agent, support of body recovery and normalisation of systemic functions, it could be speculated that increased SAA concentrations were an in vivo effect of feverfew, associated with its antibacterial activity as SAA blocks cellular receptors and thus, the influence of bacteria and their products on them (Burgess et al., 2018). Also, it is an opsonin and retinol-binding protein (Shah et al., 2006; Liu et al., 2016). Further studies are however needed to support this hypothesis.

Serum free sialic acid concentrations in controls ranged between $1.65-2.3 \mathrm{mmol} / \mathrm{L}$ and increased statistically significantly $(\mathrm{p}<0.01)$ in dogs from Group II and III by post infection hour 72 with ranges of $2.68-3.38 \mathrm{mmol} / \mathrm{L}$ and $2.33-4.4 \mathrm{mmol} / \mathrm{L}$ respectively. The recorded elevation was not attributed to infectious agent specifics, as in rats infected with Trichinella spiralis Ivanov et al. (2014) observed similar changes. The findings about increased free sialic acid blood levels in dogs with $P$. aeruginosa skin and soft tissue infection, treated or not with feverfew at post infection hours 48 and 72 are in line with many other reports (Mohebbi et al., 2010; Khoshvaghti and Nazifi, 2012; Nazifi et al., 2012) interpreting sialic acid as an APPs. Ghoshal et al. (2010) commented the correlation between sialic acid and nitric oxide, while in this experimental model, SAA and SA concentrations were strongly associated only in the infected and feverfew treated group (rho=0.410, $\mathrm{P}=0.0086, \mathrm{n}=40$ ) .

In conclusion, the changes of SAA and SA levels in dogs subcutaneously infected with $P$. aeruginosa were specific for acute phase response, but the concentrations of both APPs were not indicative for bacterial skin and soft tissue infections. The administration of feverfew to infected animals increased markedly the blood levels of both, in particular those of SAA, which reflected one of in vivo effects of this phytopreparation in this canine skin infection model. 
Acknowledgements: Our heartiest thanks to Mrs Daniela Ivanova, Faculty of Veterinary Medicine, for her technical assistance in preparing this manuscript.

\section{REFERENCES}

Alhazmi, A. (2015). Pseudomonas aeruginosa Pathogenesis and Pathogenic mechanisms. Int. J. Biol. 7(2): 44-67.

Andonova, M., V. Urumova, D. Dimitrova, E. Slavov, P. Dzhelebov, T. Chaprazov, and I. Borissov (2015). Evaluation of nuclear factor kappa beta, nitric oxide and blood neutrophil/lymphocyte ratio as biomarkers of inflammatory response and complementary therapy in dogs with experimental skin Pseudomonas aeruginosa infection. Adv. Anim. Vet. Sci. 3: 174-182. http://dx.doi.org/10.14737/journal.aavs/2015/3.3 174.182

Andonova, M., V. Urumova, D. Dimitrova, E. Slavov, P. Dzhelebov, T. Chaprazov, and T. Georgieva (2016). Acute phase response and the effect of the phytopreparation Feverfew (Tanacetum parthenium) in dogs with experimental Pseudomonas aeruginosa skin infection. BJVM 19(1): 72-77.

Andonova, M., E. Slavov, P. Dzhelebov, V. Urumova, D. Dimitrova, and M. Lyutskanov (2017). Effects of Feverfew (Tanacetum parthenium) and antibiotic co-administration on blood neutrophil function and serum procalcitonin in dogs with experimental subcutaneous Pseudomonas aeruginosa infection. J. Anim. Plant Sci. 27(2): 430-438.

Burgess, E.J., L.R. Hoyt, M.J. Randall, M.M. Mank, J.J. Bivona, and P.L. Eisenhauer (2018). Bacterial lipoproteins constitute the TLR2-stimulating activity of serum amyloid A. J. Immunol. DOI: 10.4049/jimmunol.1800503.

Buttke, T.M., G. Shipper, E. Delano, and M. Trope (2005). C-reactive protein and serum amyloid A in a canine model of chronic apical periodontitis. J. Endod. 31(10): 728-732.

Cabot, G., A.A. Ocampo-Sosa, M.A. Domínguez, J.F. Gago, C. Juan, F. Tubau, C. Rodríguez, B. Moyà, C. Peña, L. Martínez-Martínez, and A. Oliver (2012). Genetic markers of widespread extensively drug-resistant Pseudomonas aeruginosa high-risk clones. Antimicrob. Agents Chemother. 56(12): 6349-6357.

Ceron, J.J., P. Eckersall, and S. Martinez-Subiela (2005). Acute phase proteins in dogs and cats: current knowledge and future perspectives. Vet. Clin. Pathol. 34(2): 85-99.

Chen, C.F. and C.H. Cheng (2009). Regulation of Cellular Metabolism and Cytokines by the
Medical Herb Feverfew in the Human Monocytic THP-1 Cells. eCAM 6(1): 91-98.

Christensen, M., S. Jacobsen, T. Ichiyanagi, and M. Kjelgaard-Hansen (2012). Evaluation of an automated assay based on monoclonal antihuman serum amyloid A (SAA) antibodies for measurement of canine, feline, and equine SAA. Vet. J. 194(3): 332-337.

Christensen, M.B., R. Langhorn, A. Goddard, E.B. Andreasen, E. Moldal, A. Tvarijonaviciute, J. Kirpenteijn, S. Jakobsen, F. Persson, and M. Kjelgaard-Haisen (2013). Canine Serum Amyloid A (SAA) Measured by Automated Latex Agglutination Turbidimetry Is Useful for Routine Sensitive and Specific Detection of Systemic Inflammation in a General Clinical Setting. Vet. Med. Sci. 75(4): 459-466.

Christensen, M.B., R. Langhorn, A. Goddard, E.B. Andreasen, E. Moldal, A. Tvarijonaviciute, J. Kirpensteijn, S. Jakobsen, F. Persson, and M. Kjelgaard-Hansen (2014). Comparison of serum amyloid $A$ and C-reactive protein as diagnostic markers of systemic inflammation in dogs. Can. Vet. J. 55(2): 161-168.

Chu, C., S. Moriyama, Z. Li, L. Zhou, A. Flamar, C.S.N. Klose, J.B. Moeller, G.G. Putzel, D.R. Withers, G.F. Sonnenberg, and D. Artis (2018). Antimicrobial Functions of Group 3 Innate Lymphoid Cells in Gut Associated Lymphoid Tissues Are Regulated by G-Protein-Coupled Receptor 183. Cell Reports 23(13): 3750-3758.

Citil, M., V. Gunes, G. Karapehlivan, G. Atalan, and S. Marasli (2004). Evaluation of serum sialic acids an inflammation marker in cattle with traumatic reticuloperitonitis. Rev. Med. Vet. 155(7): 389-392.

Cray, C., J. Zaias, and N.H. Altman (2009). Acute phase response in animals: a review. Comp. Med. 59(6): 517-526.

Donadio, S., S. Maffioli, P. Monciardini, M. Sosio, and D. Jabes (2010). Antibiotic discovery in the twenty-first century: current trends and future perspectives. J. Antibiot. 63(8): 423-430.

Eckersall, P.D. and R. Bell (2010). Acute phase proteins: Biomarkers of infection and inflammation in veterinary medicine. Vet. J. 185(1): 23-27.

Farzaneh, M., M. Ahmadzadeh, and J. Hadian (2002). Chemical composition and antifungal activity of essential oils of three species of Tanacetum on some soil borne phytopathogens. Flav. Frag. J. 17(2): 150-152.

Fu, W., T. Forster, O. Mayer, J.J. Curtin, S.M. Lehman, R.M. Donlan (2010). Bacteriophage cocktail for the prevention of biofilm formation by Pseudomonas aeruginosa on catheters in an in 
vitro model system. Antimicrob. Agent Chemother. 54(1): 379-404.

George, V.C., D.R.N. Kumat, P.K. Suresh and R.A. Kumar (2012). A review on the therapeutic potentials of parthenolide: a sesquiterpene lactone. Int. Res. J. Pharmacy 3(2): 69-73.

Ghoshal, U.C., R. Chaturvedi, and P. Correa (2010). The enigma of Helicobacter pylori infection and gastric cancer. Indian J. Gastroenterol. 29(3): 95-100.

Hadẑimusić, N., and A. Hrković (2018). C-reactive Protein and Serum Amyloid A in Male Dogs after Orchiectomy. Erciyes Üniv. Vet. Fak. Derg. 15(1): 37-40.

Hartnell, A., J. Steel, H. Turley, M. Jones, D.G. Jackson, and P.R. Crocker (2001). Characterization of human sialoadhesin, a sialic acid binding receptor expressed by resident and inflammatory macrophage populations. Blood 97(1): 288-296.

He, J., R.L. Baldini, E. Deziel, M. Saucier, Q. Zhang, and N.T. Liberati (2004). The broad host range pathogen Pseudomonas aeruginosa strain pa14 carries two pathogenicity islands harboring plant and animal virulence genes. Proc. Natl. Acad. Sci. USA 101(8): 2530-2535.

Heunis, T.D.J. and L.M.T. Dicks (2010). Nanofibers offer alternative ways to treatment of skin infections. J. Biomed. Biotech. 510682, http://dx.doi.org/10.1155/2010/510682.

Hulten, C., K. Sletten, C.F. Bruun, and G. Marhaug (1997). The acute phase serum amyloid A protein (SAA) in the horse: isolation and characterization of three isoforms. Vet. Immunol. Immunopathol. 57(3-4): 215-227.

Ivanov, D., R. Milcheva, S. Petkova, and M. Gabrashanska (2014). Serum sialic acid levels in Trichinella Spiralis infected rats. Comptes rendus de l'Academie bulgare des Sciences 67(2): 217-222.

Izadi, Z., M. Esna-Ashari, K. Piri, and P. Davoodi (2010). Chemical composition and antimicrobial activity of feverfew (Tanacetum parthenium) essential oil. Int. J. Agric. Biol. 12(5): 759-763.

Izadi, Z., M. Aghaalikhani, M. Esna-Ashari, P. Davoodi (2013). Determining Chemical Composition and Antimicrobial Activity of Feverfew (Tanacetum parthenium L.) Essential Oil on Some Microbial Strains. ZJRMS 15(6): 8-13.

Izumi, E., L.G. Morello, T. Unda-Nakamura, S.F. Yamada-Ogatta, B.P.D. Filho, D.A.G. Cortez, I.C.P Ferreira, J.A. Morgado-Diaz, and C.V. Nakamura (2008). Trypanosoma cruzi: antiprotozoal activity of parthenolide obtained from Tranacetum parthenium (L.) Schultz Bip. (Asteraceae, Compositae) against epimastigote and amastigote forms. Exp. Parasitol. 118(3): 324-330.

Jain, S., V. Gautam, and S. Naseem (2011). Acute-phase proteins: As diagnostic tool. J. Pharm. Bioall. Sci. 3(1): 118-127.

Jitpean, S., A. Pettersson, O.V. Hoglund, B.S. Holst, U. Olsson, and R. Hagman (2014). Increased concentrations of serum amyloid $\mathrm{A}$ in dogs with sepsis caused by pyometra. BMC Vet. Res. 10: 273-281. DOI:10.1186/s12917-014-0273-9

Kim, M.H., M.C. de Beer, J.M. Wroblewski, N.R. Webb, and F.C. de Beer (2013). SAA does not induce cytokine production in physiological conditions. Cytokine 61(2): 506-512

Khoshvaghti, A. and S. Nazifi (2012). Evaluation of Inflammatory Mediators (Sialic Acid, Tumor Necrosis Factor alfa and Inrerferon gamma) and Acute Phase Proteins (Haptoglobin, Serum Amiloid alfa and alfa 1-acid Glycoprotein) and Relationship Between These Parameters in Healthy Ostriches. Glob. Vet. 8(4): 374-380.

Kjelgaard-Hansen, M. and S. Jacobsen (2011). Assay validation and diagnostic applications of major acute-phase protein testing in companion animals. Clin. Lab. Med. 31(1): 51-70.

Langhorn, R., M. Oyama, L. King, M.C. Machen, D.J. Trafny, V. Thawley, J.L. Willesen, I. Tarnow, and M. Kjelgaard-Hansen (2013). Prognostic importance of myocardial injury in critically ill dogs with systemic inflammation. J. Vet. Int. Med. 27(4): 895-903.

Lavoie, E.G., T. Wangdi, and B. Kazmierczak (2011). Innate immune response to Pseudomonas aeruginosa infection. Microb. Infect. 13(14-15): 1133-1145.

Liu, J., D. Wang, S.Q. Li, Y. Yu, and R.D. Ye (2016). Suppression of LPS induced tau hyperphosphorylation by serum amyloid A. J. Neuroinflamm. 13: 28. DOI: 10.1186/s12974016-0493-y

Martin, K., R. Sur, F. Liebel, N.K. Tierney, P. Lyte, M. Garay, O. Thierry, M. Anthonavage, S. Shapiro, and M. Southall (2008). Parthenolide-depleted Feverfew (Tanacetum parthenium) protects skin from UV irradiation and external aggression. Arch. Dermatol. Res. 300(2): 69-80. https://doi.org/10.1007/s00403-007-0818-x

Mathema, V.B., Y. Koh, B.C. Thakuri, and M. Sillanpää (2012). Parthenolide, a Sesquiterpene Lactone, Expresses Multiple Anti-cancer and Antiinflammatory Activities. Inflammation 35(2): 560-565.

Meek, R.L. and E.P. Benditt (1986). Amyloid A gene family expression in different mouse tissues. J. Exp. Med. 164(6): 2006-2017. 
Mohebbi, M., J. Sajedianfarad, S. Nazifi, and A.S. Samimi (2010). Changes of serum amyloid A, haptoglobulin, ceruloplasmin, fibrinogen and lipid-associated sialic acid in sheep fed high grain rations with altered digestive functions. Com. Clin. Pathol. 19(6): 541-546.

Murata, H., N. Shimada, and M. Yoshioka (2004). Current research on acute phase proteins in veterinary diagnosis: an overview. Vet. J. 168(1): 28-40.

Nascimento, G., J. Locatell, and C. Freitas (2000). Antibacterial activity of plant extract and phytochemical on antibiotic resistant bacteria. Braz. J. Microbiol. 31(2): 347-351.

Nazifi, S., A. Oryan, M. Ansari-Lari, M.R. Tabandeh, A. Mohammadalipour, and M. Gowharnia (2012). Evaluation of sialic acids and their correlation with acute-phase proteins (haptoglobin and serum amyloid A) in clinically healthy Iranian camels (Camelus dromedaries). Com. Clin. Pathol. 21(4): 383-387.

Pareek, A., M. Suthar, G. Rathore, and V. Bansol (2011). Feverfew: A systematic review. Pharmacogn. Rev. 5(9): 103-110.

Petersen, H.H., J.P. Nielsen, and P.M.H. Heegaard (2004). Application of acute phase protein measurements in veterinary clinical chemistry. Vet. Res. 35(2): 163-187.

Polatoğlu, K., F. Demirci, B. Demirci, N. Gören, and K.H.C. Baser (2010). Antibacterial activity and the variation of Tanacetum parthenium (L) Schultz Bip. J. Oleo. Sci. 59(4): 177-184.

Polatoğlu, K., O.C. Karakoç, A. Gőkçe, and N. Gőren (2011). Insecticidal activity of Tanacetum chiliophyllum (Fisch. \& Mey.) var. monocephalum Grierson extracts and a new sesquiterpene lactone. Phytochem. Let. 4(4): 432-435.

Pourianezhad, F., S. Tahmasebi, V. Abdusi, S. Nikfar, and M. Mirhoseini (2016). Review on feverfew, a valuable medicinal plant. J. Herb. Pharmacol. 5(2): 45-49.

Quinn, P.J., M.E. Carter, B.K. Markey and G.R. Carter (1999). Bacteriology. Pseudomonas species. In: Clinical Veterinary Microbiology, Harcourt Publishers, section 2: 237-243.

Sack, G.H.Jr. (2018). Serum amyloid A - A review. Mol. Med. 24(1): 46. DOI: 10.1186/s10020-0180047-0

Saewan, N. and A. Jimtaisong (2013). Photoprotection of natural flavonoids. J. Appl. Pharmaceutic. Sci. 3 (09): 129-141.

Sawa, S., M. Lochner, N. Satoh-Takayama, S. Dulauroy, M. Bérard, M. Kleinschek, D. Cua, J.P. Di
Santo, and G. Eberl (2011). ROR $\gamma \mathrm{t}+$ innate lymphoid cells regulate intestinal homeostasis by integrating negative signals from the symbiotic microbiota. Nat. Immunol. 12(4): 320-326.

Schmidt, E.M. and P.D. Eckersall (2015). Acute phase proteins as markers of infectious diseases in small animals. Acta Vet. Beograd 65(2): 149-161.

Sellar, G.C., M.C. DeBeer, J.M. Lelias, P.W. Snyder, L.T. Glickman, P.J. Felsburg, and A.S. Whitehead (1991). Dog serum amyloid A protein. Identification of multiple isoforms defined by cDNA and protein analyses. J. Biol. Chem. 266(6): 3505-3510.

Shah, C., R. Hari-Dass, and J.G. Raynes (2006). Serum amyloid $\mathrm{A}$ is an innate immune opsonin for Gram-negative bacteria. Blood 108(5): 1751-1757.

Shamberger, R.J. (1984). Serum sialic acid in normals and cancer patients. J. Clin. Chem. Clin. Biochem. 22(10): 647-651.

Smolinski, A.T. and J.J. Pestka (2003). Modulation of lipopolysaccharide induced proinflammatory cytokine production in vitro and in vivo by the herbal constituents apigenin chamomile ginsenoside $\mathrm{Rb} 1$ ginseng and parthenolide feverfew. Food Chem. Toxicol. 41(10): 13811390.

Smolinski, A.T. and J.J. Pestka (2005). Comparative effects of the herbal constituent parthenolide (Feverfew) on lipopolysaccharide induced inflammatory gene expression in murine spleen and liver. J. Inflam. 2: 6. DOI:10.1186/14769255-2-6

Sydow, G. (1985). A simplified quick method for determination of sialic acid in serum. Biomed. Biochim. Acta 44(11-12): 1721-1723.

Uluçкаn, Ö., J. Guinea-Viniegra, M. Jimenez, and E.F. Wagner (2015). Signalling in inflammatory skin disease by AP-1 (Fos/Jun). Clin. Exp. Rheumatol. 33(Supp. 92): S44-S49.

Upragarin, N., W.J.M. Landman, W. Gaastra and E. Gruys (2005). Extrahepatic production of acute phase serum amyloid A. Histol. Histopathol. 20: 1295-1307. DOI:10.14670/HH-20.1295

Yamamoto, S., K. Tagata, Y. Ishikawa, H. Santsuka, M. Yamada, M. Morimatsu, and M. Naiki (1993). Avidity of antibody and agglutinability of antibody-sensitized latex in latex agglutination test. Vet. Immunol. Immunopathol. 36(3): 257264. 